\title{
Vulkansk sang - fra vals til hard rock
}

\section{Af GeologiskNyts webmaster Steen Laursen}

Musik kan digitaliseres, og så er det jo bare en masse tal. Heraf følger, at en masse tal også kan laves til musik. Der skal bare lige sættes en computer til.

Vulkanen Tungurahua i Ecuador har været i gang med et udbrud siden 1999, og midt $i$ august $i$ år kom der så meget tryk på, at aviserne skrev om det herhjemme. Vulkanen har med andre ord spillet op til bal i årevis, og musikken til det kan vi nu høre takket være den italienske fysiker Roberto Barbera fra universitetet i Catania.

\section{Fra seismik til musik}

Det rigtigste er måske at sige, at han har taget seismik fra Tungurahua og Etna i Italien som inspiration til musik, for sådan lige umiddelbart er der ikke meget at høre. På de to vulkaner er der enten stille eller

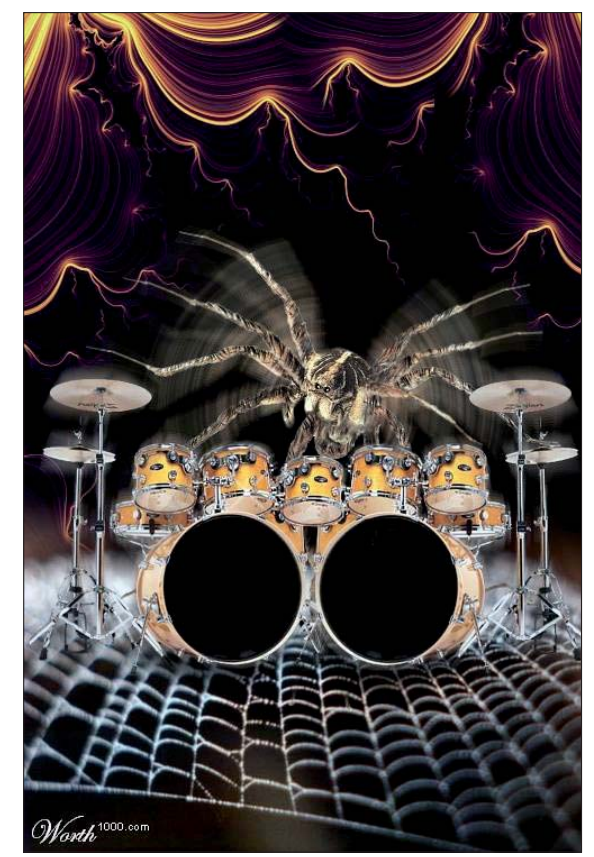

Computergenereret jordmusik på nettet. (Billedemanipulation: Worth1000.com)

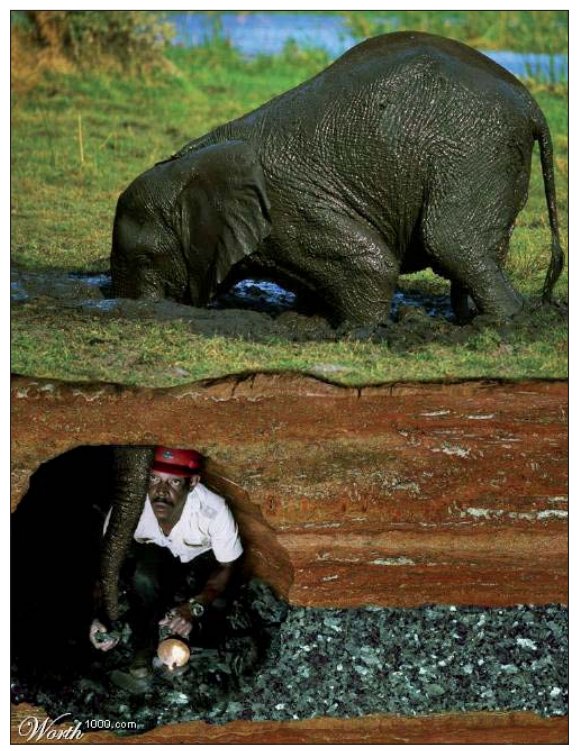

Afrikansk jordmusik. (Billedemanipulation: Worth1000.com)

fuld knald på. Men ved at køre de seismiske målinger på dem igennem et par rigtigt store computere og så sende dem videre igennem et MIDI-klaver, har han alligevel fået musik ud ad det.

Formålet med øvelsen - for sådan et er der også - er, at det menneskelige øre er i stand til at finde mønstre i noget, der er tæt på rent kaos. Øjet kan også godt finde mønstre i kaos, men det lader sig lettere forstyrre af de mange indtryk. Øret skærer derimod let støjen fra." "The human ear is a logorithmic device," forklarer Roberto Barbera til Nerwscientist.

\section{Fra vals til rock}

Det er så tanken, at når mønstret i de seismiske målinger ændrer sig, kan det være et tegn på, at vulkanen er ved at gå i udbrud. Man kan sige, at når vulkanen skifter til en ny melodi, skifter dansen fra let vals til heavy rock. Metoden er faktisk brugt med succes inden for andre grene af naturvidenskaben, men den har endnu ikke forudsagt et vulkanudbrud.

Roberto har lagt den underjordiske musik på nettet, og det første indtryk er nok, at

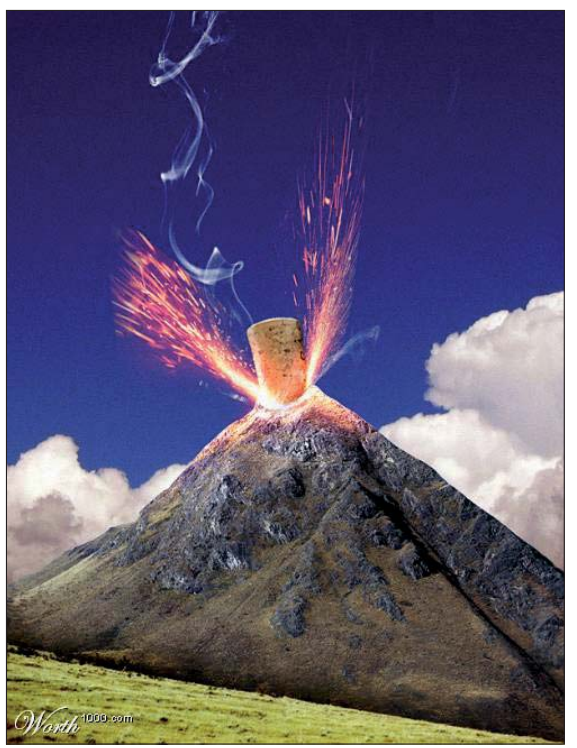

Vulkaner skifter melodien, når proppen går. (Billedemanipulation: Worth1000.com)

musikken er ret moderne. Men der er tydelig forskel på de to vulkaner. Hvor Etna holder sig til hurtige skift i de lyse toner, er der langt mere afveksling i Tungurahuas melodi. To musik-links findes i boksen nedenfor.

\section{Jordmusik}

Men selv dagligdags jord har rytme. Musikeren Niels Lan Doky har fundet ud af, at man kan sende forskellige målinger på almindelig jord igennem en computer og få musik ud af det, og det har han så optrådt med i Tivolis Koncertsal. Han har fundet melodien i 163 jordprøver fra hele Jorden, og andet sæt i koncertsalen den 2. juli i år begyndte med jordmusik fra Marokko. Politikens journalist på stedet ærgrede sig over, at salens dårlige akustik ødelagde oplevelsen.

\section{Links til lydfilerne:}

http://grid.ct.infn.it/tungurahuasound/ TungurahuaPiano.aif

http://grid.ct.infn.it/etnasound/page4/ page8/etna.aif 